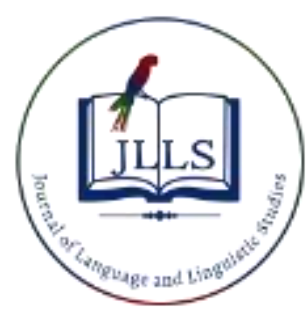

Available online at www.jlls.org

JOURNAL OF LANGUAGE AND LINGUISTIC STUDIES

ISSN: $1305-578 \mathrm{X}$

Journal of Language and Linguistic Studies, 16(2), 1006-1018; 2020

\title{
Usage of English speech like expressions in Turkish students' written works
}

\author{
Kadriye Aytaç-Demirçivi a 1 (D \\ APA Citation: \\ ${ }^{a}$ Aksaray University, Aksaray, Turkey \\ Aytaç-Demirçivi, K. (2020). Usage of English speech like expressions in Turkish students' written works. Journal of Language and \\ Linguistic Studies, 16(2), 1006-1018. \\ Submission Date: $15 / 01 / 2020$ \\ Acceptance Date: 13/02/2020
}

\begin{abstract}
The present study investigates the usage of speech like expressions in written works of Turkish learners of English. It also aims to find out the differences between $\mathrm{C} 1$ and $\mathrm{B} 1$ level learners in terms of the frequency and types of speech like expressions. The participants in this study were $21 \mathrm{~B} 1$ and $33 \mathrm{C} 1$ level students at a state university in Turkey. For this study, students' writing assignments were collected. For the frequency analysis, manual counting of the words was used. For the types of speech like expressions, the data were divided into different groups of speech like expressions based on the framework of previous studies. The analysis of the data showed that B1 level learners use speech like expressions much more commonly than $\mathrm{C} 1$ level learners. In addition, there were also some differences in terms of the types of the speech like expressions used by $\mathrm{C} 1$ and $\mathrm{B} 1$ level learners.
\end{abstract}

(C) 2020 JLLS and the Authors - Published by JLLS.

Keywords: speech like expressions; writing; C1 learners; B1 learners; Turkish learners of English

\section{Introduction}

\subsection{Spoken and Written Language}

There are several differences between spoken and written language. They are regarded as different in terms of their purposes, physical nature and the kind of language that is used. Firstly, in terms of their purposes, Olson (1977) implies that speech is a common sense language while writing is used to represent scientific and philosophical knowledge. Therefore, it might be possible to indicate that speech is more informal than written language. As for their physical nature, as indicated by Schallert, Kleiman and Rubin (1977), speech includes more auditory information and prosodic features such as rhythm, stress and intonation which are not found in written language. Speech is also regarded as more temporary compared to writing. Contrary to speech, written language includes more visual information and it is more permanent. Finally, in terms of the language used in speech and writing, as indicated by Devito (1965) speech is considered to include more repetition and more words since it is usually unplanned and spontaneous. There is usually not any opportunity for editing speech. On the other hand, written language is believed to be longer. In addition, it includes less common and less redundant words. Written

\footnotetext{
${ }^{1}$ Corresponding author. Tel.: +90-382-288-2286

E-mail address: aytackadriye@gmail.com
} 
language is also believed to be syntactically more complex than speech as writers have the opportunity to choose and edit their words in writing.

\subsection{General Features of Spoken English}

As indicated by Cullen and Kuo (2007), contrary to written language, spoken language is mostly unplanned and spontaneous. There is not any opportunity for editing. Therefore, this results in some distinct features of spoken language. Hilliard (2014) identifies six different features of spoken English which are ellipsis, head, tails, fillers and backchannels and phrasal chunks. Hillard (2014) indicates that ellipsis is the omission of certain elements. To illustrate, instead of saying "Do you have any questions?", speakers might say "Any questions?" which is considered to be more informal. Cullen and Cuo (2007) point out that heads introduce a topic before giving further information as might be seen in the following examples.

1 The soccer game last night, it was really exciting. (With head)

2 The soccer game last night was really exciting. (No head)

Another feature of spoken English is tails which are added at the end of a phrase. In the examples below, the first sentence includes a tail while the second one does not.

3 My teacher is really nice, the one from America. (With tail)

4 My teacher from America is really nice. (No tail)

The next feature identified for spoken English is fillers and backchannels. Willis (2003) indicates that fillers include words like er, well, hmm, and um. These words do not have any meaning. On the other hand, Stenström (2004) points out that backchannels are words or utterances such as $u h-h u h$, oh, yeah, and I see which are used to encourage the speaker to continue. In addition, phrasal chunks are also regarded as a feature of spoken English. Cullen and Kuo (2007) indicate that phrasal chunks include sort of, kind of, stuff like that, a bit, a little bit, you know and I mean.

In addition to these six features, there are also other expressions which have been defined as features of spoken language. To exemplify, Tannen (1984) indicates that clause combining words such as and, but, so and because are considered to be more informal and speech like compared to other conjunctions such as in addition, therefore, on the contrary and since. Moreover, Simcikaite (2012) indicates that discourse markers such as well, oh, like, of course, yeah, right are also regarded as features of spoken language. Lastly, as indicated by Park (2007) contracted forms of auxiliary verbs, usage of phrasal verbs and $a$ lot of, lots of and a lot instead of much and many are also included in the features of spoken English. Based on these different categories identified for features of spoken English which include ellipsis, head, tails, fillers, backchannels, phrasal chunks, combining words such as and, but and so, contracted forms of auxiliary verbs, phrasal verbs and usage of a lot of, lots of and a lot instead of much and many, the data for this study were analysed in order to find out the occurrences of these features. Moreover, based on the data, several other categories for speech like expressions were also identified that were not referred to in previous literature.

\subsection{Usage of Speech Like Expressions in Writing}

There have been several studies on the usage of speech like expressions in written language. To start with, Babanoğlu (2014) investigated the usage of pragmatic markers in the written texts of Turkish learners of English. This study also aimed to compare Turkish learners of English with native speakers in terms of their usage of speech like expressions in writing. The data were gathered from three different corpora which are Turkish Corpus of Learner English, Japanese Corpus of Learner English and Louvain Corpus of Native English Essays. She found out that students tend to use oral features in their 
argumentative essays and this might influence their writing negatively in terms of its style. The results also indicated that Turkish and Japanese EFL learners use certain pragmatic markers more commonly compared to native speakers.

In a similar study investigating the difference between learner corpus and native speaker corpus, Gilquin and Paquot (2007) tried to compare learner corpus data with written and spoken native corpus data. The results indicated that learners tend to use more speech like expressions when organizing their academic writing. They also tried to present some reasons for the usage of spoken features in academic writing. Some of these reasons include register confusion, L1 transfer, L2 instruction and developmental factors.

In another study, Simcikaite (2012) also compared L2 learners and native speakers in terms of their use of spoken features in academic writing. He found out that both Lithuanian learners and native speakers use speech like expressions in their essays. Moreover, in accordance with the results of the study by Babanoğlu (2014), the results indicated that Lithuanian learners tend to use more spoken discourse markers in their academic writing compared to native speakers.

Although previous studies focused on speech like expressions in students' written words, there has not been much focus on the comparison of different proficiency levels in terms of their usage of speech like expressions. Therefore, this study aims to investigate the speech like expressions used in written works of Turkish learners of English. Moreover, it also aims to investigate the differences between $\mathrm{C} 1$ and B1 level learners in terms of the frequency and types of speech-like expressions.

Based on this framework, the present study aims to investigate the following research questions:

1) What is the frequency of speech like expressions used by $\mathrm{C} 1$ level learners?

2) What is the frequency of speech like expressions used by B1 level learners?

3) What types of speech like expressions are used by $\mathrm{C} 1$ level learners?

4) What types of speech like expressions are used by B1 level learners?

5) Does the students' proficiency level of English have an effect on the frequency and types of speech like expressions used in their written works?

\section{Method}

\subsection{Sample / Participants}

The relevant data for the present study were collected from 21 preparatory class students and 33 first grade students at a state university in Turkey. Both preparatory class students and first grade students are studying at the department of English Language Teaching. There are 5 male and 16 female students in the preparatory class and they are B1 level students. On the other hand, there are 21 female and 12 male students in the first grade class who are $\mathrm{C} 1$ level students.

\subsection{Data collection procedures}

For Contextual Grammar course, $\mathrm{C} 1$ level learners are preparing an assignment each week for the topics assigned by the instructor. In these assignments, they are expected to use specific grammar items several times. Their assignment consists of three or four paragraphs. For the current assignment that was collected for this study, the students were asked to write either on benefits or drawbacks of sport or women in combat. 
For Writing course, the students are writing paragraphs every week. These paragraphs consist of 1215 sentences about specific topics assigned by the instructor. For the current assignment, the students were asked to write on either advantages or disadvantages of studying at preparatory class or whether the students should be required to take a university entrance exam.

\subsection{Data analysis}

The data were analysed for the frequency and types of speech like expressions. For the frequency analysis, manual counting of the words was used. Since the data for B1 and C1 level learners are not the same in terms of their size, normalized frequencies were used in order to be able to compare the data in terms of their frequency. For the types of speech like expressions, the data were divided into different groups of speech like expressions based on the framework of previous studies.

\section{Results}

\subsection{Frequency Analysis}

For the frequency analysis, all of the words in the data were counted manually. Then all of the speech like expressions were counted in the data of $\mathrm{C} 1$ and $\mathrm{B} 1$ level learners.

Table 1. Total Number of Words in the Data

\begin{tabular}{lll}
\hline Level & $\mathrm{C} 1$ & $\mathrm{~B} 1$ \\
\hline Total number of words & 6961 & 2990 \\
\hline
\end{tabular}

As can be seen in Table 1, the total number of the words in C1 level data is 6961 and it is 2990 for B1 level data.

Table 2. Total number of speech like expressions in the data

\begin{tabular}{lll}
\hline Level & C1 & B1 \\
\hline Total number of speech like expressions & 253 & 190 \\
Normalized frequency (per thousand) & 36.34 & 63.54 \\
\hline
\end{tabular}

As Table 2 illustrates, normalized frequency of speech like expressions for $\mathrm{C} 1$ level learners is 36,34 while it is 63,54 for B1 level learners. These results indicate that B1 level learners use speech like expressions much more commonly than $\mathrm{C} 1$ level learners.

\subsection{Types of Speech Like Expressions}

The data were carefully examined for the types of speech like expressions and 12 different categories for $\mathrm{C} 1$ level learners' data were identified including (1) contractions, (2) lots of/ a lot of/ a lot, (3) phrasal verbs, (4) omission of relative pronouns, (5) syntax, (6) because, (7) and, (8) so, (9) but, (10) like instead of such as, (11) place of adverbs and (12) other expressions. 10 different categories for B1 level learners' data were identified. These categories are (1)contractions, (2) lots of/ a lot of/ a lot, (3) phrasal verbs, (4) syntax, (5) because, (6) and, (7) so, (8) but, (9) place of adverbs and (10) other expressions. B1 level data was missing the categories omission of relative pronouns and usage of like instead of such as. 


\subsubsection{Contractions}

As can be seen in Table 3, there are 70 occurrences of contractions in the $\mathrm{C} 1$ level data. Contractions are the most commonly used speech like expressions by $\mathrm{C} 1$ level learners. As is the case with the $\mathrm{C} 1$ level learners, the most common speech like expression used by the $\mathrm{B} 1$ level learners is contractions. As can be seen in Table 3, there are 49 occurrences of contractions in the B1 level data.

Table 3. Total number of contractions in the $\mathrm{C} 1$ and $\mathrm{B} 1$ level data

\begin{tabular}{llc}
\hline Level & C1 & B1 \\
Number of contractions & 70 & 49 \\
Per thousand & 10.05 & 16.38 \\
\hline
\end{tabular}

As can be seen in Table 4, the contractions used by $\mathrm{C} 1$ level learners are mostly the contractions of negative auxiliaries. The most common contraction is don't. There are 5 occurrences of positive contractions which are I've, should've, they're, I'll and it's. Table 4 also illustrates the contractions used by B1 level learners and their frequency. As is shown in the table, the most common contractions are don't and couldn't. As is the case with the $\mathrm{C} 1$ level learners, most of the contractions are the negative forms of auxiliary verbs. It's and I'm are the only contractions which are the positive forms of auxiliary verbs.

Table 4. List and frequency of the contractions in the $\mathrm{C} 1$ and $\mathrm{B} 1$ level data

\begin{tabular}{lll}
\hline Contraction & C1 & B1 \\
\hline don't & 27 & 11 \\
can't & 9 & 1 \\
\hline shouldn't & 9 & 4 \\
\hline isn't & 3 & 1 \\
\hline wouldn't & 2 & 0 \\
\hline won't & 1 & 0 \\
\hline aren't & 1 & 2 \\
\hline couldn't & 1 & 11 \\
\hline I've & 1 & 0 \\
\hline should've & 1 & 0 \\
wasn't & 1 & 1 \\
\hline didn't & 1 & 6 \\
\hline hasn't got & 1 & 0 \\
they're & 1 & 0 \\
\hline haven't & 1 & 1 \\
\hline I'll & 1 & 0 \\
\hline I'm not & 1 & 0 \\
\hline
\end{tabular}




\begin{tabular}{lll}
\hline doesn't & 1 & 3 \\
\hline it's & 1 & 4 \\
\hline I'm & 0 & 3 \\
\hline needn't & 0 & 1 \\
\hline
\end{tabular}

\subsubsection{Lots of/ a lot of/ a lot}

Compared to much and many, lots of, a lot of and a lot are regarded as more informal and speech like expressions. As is illustrated in Table 5, there are 11 occurrences of these words in C1 level data. As already indicated, lots of, a lot of and a lot are regarded as more informal compared to much and many. In B1 level data, there are 3 occurrences in which the students used these words instead of much and many.

Table 5. Total number of lots of/a lot of/ a lot in the C1 and B1 level data

\begin{tabular}{lll}
\hline Level & $\mathrm{C} 1$ & $\mathrm{~B} 1$ \\
Number of occurrences & 11 & 3 \\
\hline Per thousand & 1.58 & 1 \\
\hline
\end{tabular}

An example sentence in which an $\mathrm{C} 1$ level student used a lot of might be seen below:

1 A lot of people died because of sport.

Below is an example sentence including lots of from B1 level data:

2 We will get lots of experiences.

\subsubsection{Phrasal Verbs}

The next type of speech like expressions is phrasal verbs. Usage of phrasal verbs is regarded as more informal compared to one word verbs. As can be seen in Table 6, there are 20 occurrences of phrasal verbs in the data of $\mathrm{C} 1$ level learners while there are 2 occurrences of phrasal verbs in $\mathrm{B} 1$ level data.

Table 6. Total number of phrasal verbs in the $\mathrm{C} 1$ and $\mathrm{B} 1$ level data

\begin{tabular}{lll} 
Level & C1 & B1 \\
\hline Number of occurrences & 20 & 2 \\
\hline Per thousand & 2.87 & 0.66 \\
\hline
\end{tabular}

As can be seen in the following examples, some of the phrasal verbs used by $\mathrm{C} 1$ level students include take up, give up, pick somebody up and close down.

3 Since they are bored with business life, they want to take up a new activity.

4 Because of expenses or debt, many children have to give up their dreams.

5 He called us to pick him up.

6 It has been estimated that 34 stadiums have been closed down.

The examples of B1 level students' sentences including phrasal verbs are provided below. As can be seen in the examples, the students used the phrasal verbs knock out and drop out.

7 This kind of exams have knocked students out for years. 
8 If they fail, they drop out school.

\subsubsection{Omission of Relative Pronouns}

Another speech like expression is the omission of relative pronouns which are the objects of the relative clause. As Table 7 illustrates, there are 4 occurrences in which the relative pronouns were omitted by the $\mathrm{C} 1$ level learners. This category was not observed in B1 level data.

Table 7. Total number of omission of relative pronouns in the $\mathrm{C} 1$ level data

\begin{tabular}{ll}
\hline Number of occurrences & 4 \\
Per thousand & 0.57 \\
\hline
\end{tabular}

The relative pronouns which and that were omitted by the students in the following examples:

9 It was due to the incidents fanatics have caused.

10 These sports help to release your energy you have inside.

11 The best example of compassion I have witnessed occurred about eight years ago.

\subsubsection{Syntax}

In some cases, speakers might use fragments instead of complete sentences by omitting the subject or verb of the sentence. These fragments are also regarded as informal and speech like expressions. As can be seen in Table 8, there is one occurrence in the $\mathrm{C} 1$ level data in which the student used a speech like expression by using a fragment. Usage of fragments is also another speech like expression used by $\mathrm{B} 1$ level learners as is the case with the $\mathrm{C} 1$ level learners. As is illustrated in Table 8, there are 2 occurrences in which students used fragments instead of complete sentences.

Table 8. Total number of fragments in the $\mathrm{C} 1$ and $\mathrm{B} 1$ level data

\begin{tabular}{lll}
\hline Level & C1 & B1 \\
\hline Number of occurrences & 1 & 2 \\
Per thousand & 0.14 & 0.66 \\
\hline
\end{tabular}

The example of this kind of speech like expression in $\mathrm{C} 1$ level data is provided below. As can be seen in the example, the student uses a fragment which has neither a subject nor a verb.

12 Actually, not only entertainment, but also occupation, love and a high dose of pleasure.

The examples of fragments in B1 level data are provided below. In the first example, the student did not use a subject. In the second example, the student used neither a subject nor a verb.

13 May be due to excitement.

14 Such as psychological illnesses.

\subsubsection{Because}

Compared to other subordinating conjunctions such as since and as, because is considered to be more informal. As can be seen in Table 9, there are 28 occurrences of because used by $\mathrm{C} 1$ level learners and there are 17 occurrences of because in the $\mathrm{B} 1$ level data. 
Table 9. Total number of because in the $\mathrm{C} 1$ and $\mathrm{B} 1$ level data

\begin{tabular}{lll}
\hline Level & C1 & B1 \\
\hline Number of occurrences & 28 & 17 \\
\hline Per thousand & 4.02 & 5.68 \\
\hline
\end{tabular}

An example sentence including because from $\mathrm{C} 1$ level data is provided below:

15 I don't watch football matches too much because they contain violence.

An example sentence from B1 level data is provided below for because:

16 I think studying prep class is beneficial for us because we have many advantages thanks to it.

\subsubsection{And}

The next speech like expression is and. Compared to other conjunctions such as in addition and as well as, and is regarded as more informal. As illustrated in Table 10, there are 47 occurrences of and in the data of $\mathrm{C} 1$ level learners and there are 34 occurrences in which and was used by B1 level students.

Table 10. Total number of and in the $\mathrm{C} 1$ and $\mathrm{B} 1$ level data

\begin{tabular}{lll}
\hline Level & C1 & B1 \\
Number of occurrences & 47 & 17 \\
\hline Per thousand & 6,75 & 5,68 \\
\hline
\end{tabular}

One of the sentences in which an $\mathrm{C} 1$ level student used and might be seen below:

17 Unfortunately, one of my friends broke my arm accidentally and I gave up playing volleyball.

Below is an example sentence for and from B1 level data:

18 And most of us didn't speak English at high school.

\subsubsection{So}

So is another speech like expression used by the learners. As is the case with because and and, so is also considered to be an expression commonly used in spoken language compared to other conjunctions such as therefore, thus and consequently. As can be seen in Table 11, there are 12 occurrences of so in the $\mathrm{C} 1$ level data and there are also 12 occurrences of so in the data of the B1 level learners.

Table 11. Total number of so in the $\mathrm{C} 1$ and $\mathrm{B} 1$ level data

\begin{tabular}{lll}
\hline Level & $\mathrm{C} 1$ & $\mathrm{~B} 1$ \\
\hline Number of occurrences & 12 & 12 \\
\hline Per thousand & 1.72 & 4.01 \\
\hline
\end{tabular}

An example sentence from $\mathrm{C} 1$ level data for so is provided below:

19 So, from children to old people, all people like doing sport.

Below is an example for so from B1 level data:

$20 \mathrm{So}$, I believe prep class is a good opportunity for improving ourselves. 


\subsubsection{But}

The next speech like expression is the usage of but. But is regarded as more informal compared to other conjunctions such as although, even though, whereas and while. As is illustrated in Table 12, there are 20 occurrences of but in the data of the $\mathrm{C} 1$ level learners while there are 12 occurrences of but in the B1 level data.

Table 12. Total number of but in the $\mathrm{C} 1$ and $\mathrm{B} 1$ level data

\begin{tabular}{lll}
\hline Level & $\mathrm{C} 1$ & $\mathrm{~B} 1$ \\
\hline Number of occurrences & 20 & 12 \\
\hline Per thousand & 2.87 & 4.01 \\
\hline
\end{tabular}

Below is an example sentence for but from C1 data:

21 People think that togetherness would end as soon as the match ends but it is not true.

An example sentence from B1 level data for but might be seen below:

$22 \mathrm{But}$ we will be familiarized to the university thanks to the prep class.

\subsubsection{0. like instead of such as}

In spoken language, in order to give examples, like might be used in some cases instead of such as. As can be seen in Table 13, there are 6 occurrences of like in which it was used instead of such as. This category was not observed in B1 level data.

Table 13. Total number of like in the $\mathrm{C} 1$ level data

\begin{tabular}{ll}
\hline Number of occurrences & 6 \\
Per thousand & 0.86 \\
\hline
\end{tabular}

Some examples of the students' sentences for like instead of such as are provided below.

23 They want to take up a new activity like running, playing basketball, football, etc.

24 Nowadays, the best footballers like Ronaldo, Messi earns nearly 23 million dollars from matches.

\subsubsection{Place of Adverbs}

Changing the place of adverbs might affect the formality of sentences. As is shown in Table 14, there are 4 occurrences in which the place of adverbs makes the sentence more similar to spoken language. As is the case with $\mathrm{C} 1$ level learners, students sometimes use adverbs in different places of a sentence, which make these sentences similar to spoken language. As can be seen in Table 14, there are also 4 occurrences in which students used speech like expressions resulting from the place of adverbs.

Table 14. Total number of speech like expressions related to adverbs in $\mathrm{C} 1$ and $\mathrm{B} 1$ level data

\begin{tabular}{lll}
\hline Level & C1 & B1 \\
\hline Number of occurrences & 4 & 4 \\
\hline Per thousand & 0.57 & 1.33 \\
\hline
\end{tabular}


As can be seen in the following examples from $\mathrm{C} 1$ level data, using some adverbs at the beginning or at the end of the sentences might make the sentences sound more speech like.

25 To prevent our country from bad things, we need limitation, clearly.

26 Really, they look adventurous.

27 When we went to pick him up, he was really in a bad condition, mentally.

28 The key of better communication is empathy, basically.

The sentences in which B1 level students used adverbs at the beginning or at the end are provided below:

29 Already, all students enter the exam before a college or university.

30 Never, all students are the same level.

31 Your peers are studying on their work already.

32 If you want something really.

\subsubsection{Other Expressions}

In the data of the $\mathrm{C} 1$ learners, there were also other speech like expressions except for the previous groups. As can be seen in Table 15, there are 30 occurrences of these speech like expressions. B1 level learners also used other speech like expressions except for the first 9 categories. As is shown in Table 15 , in 35 occurrences students used other speech like expressions.

Table 15. Total number of other expressions in the $\mathrm{C} 1$ and $\mathrm{B} 1$ level data

\begin{tabular}{lll}
\hline Level & $\mathrm{C} 1$ & $\mathrm{~B} 1$ \\
\hline Number of occurrences & 30 & 35 \\
\hline Per thousand & 4.3 & 11.07 \\
\hline
\end{tabular}

Table 16 illustrates the other speech like expressions used by the students with their frequency. As is shown in the table, the most commonly used expression is I think followed by I believe, I hope and of course. The list of the other speech like expressions by B1 level students with their frequencies is also provided in Table 16. As can be seen in the table, the most frequent one is I think which is the same as the data of the $\mathrm{C} 1$ level learners. I think is followed by in my opinion, I cannot imagine and I mean.

Table 16. List and frequency of other expressions in the $\mathrm{C} 1$ and $\mathrm{B} 1$ level data

\begin{tabular}{lll}
\hline Other Expressions & C1 & B1 \\
\hline I think & 9 & 19 \\
\hline I believe & 3 & 1 \\
\hline I hope & 2 & 0 \\
\hline Of course & 2 & 1 \\
\hline I will address & 1 & 0 \\
I'm not convinced & 1 & 0 \\
I want to talk about & 1 & 0 \\
\hline
\end{tabular}




\begin{tabular}{lll}
\hline As I said already & 1 & 0 \\
\hline I will be telling you & 1 & 0 \\
\hline I can accept & 1 & 0 \\
\hline In my opinion & 1 & 2 \\
I personally think & 1 & 0 \\
\hline I support & 1 & 1 \\
\hline I can say that & 1 & 0 \\
So on & 1 & 1 \\
\hline Well & 1 & 0 \\
\hline Needless to say & 1 & 0 \\
\hline I agree & 1 & 1 \\
\hline I don't agree & 1 & 1 \\
\hline I can't imagine & 0 & 2 \\
\hline I mean & 0 & 2 \\
I say & 0 & 1 \\
\hline I don't know & 0 & 1 \\
I can't think & 0 & 1 \\
\hline I don't believe & 0 & 1 \\
\hline I don't complain & 0 & 1 \\
\hline
\end{tabular}

\section{Discussion}

As already indicated B1 level learners use speech like expressions much more commonly than C1 level learners. There are 12 different types of speech like expressions used by $\mathrm{C} 1$ level learners while it is 10 for B1 level learners. B1 level learners did not omit the relative pronouns in their data. This might be because of the reason that they did not use many relative clauses which is most probably because of their proficiency level. Moreover, they never used like instead of such as which might be because of their lack of practice in speaking. Although both levels use contractions, B1 level learners use them more frequently than $\mathrm{C} 1$ level learners. Lots of, a lot of, a lot and phrasal verbs are more commonly used by $\mathrm{C} 1$ learners. Common usage of phrasal verbs by $\mathrm{C} 1$ level learners might be because of their proficiency level. Speech like expressions created by fragments and place of adverbs are more commonly used by B1 level learners. In addition, because, and, but, so and other speech like expressions are also more commonly used by B1 level learners.

\section{Conclusions}

This paper shows that proficiency level, writing and speaking experience of students might be important factors which affect the usage of speech like expressions in their writing. A higher level of proficiency in English might sometimes cause a higher percentage of some specific types of speech like expressions in written works as is the case with the common usage of phrasal verbs by $\mathrm{C} 1$ level students and rare usage of relative clauses by B1 level students. On the other hand, in general, a lower level of 
proficiency in English might also be regarded as a reason for the higher percentage of speech like expressions used by B1 level students in their written works. Since they have less experience and less L2 instruction in writing, they might tend to use more informal expressions. L1 transfer might be another factor that accounts for the higher frequency of speech like expressions in B1 level students' writing. However, since $\mathrm{C} 1$ level students have more experience in writing and they know that they should avoid informal expressions in their formal writings as much as possible, they might have used fewer speech like expressions for the task of this study. Although previous studies did not compare two different learner proficiency levels, they mostly found out that learners of English use more speech like expressions compared to native speakers (see Babanoğlu, 2014; Gilquin and Paquot, 2007; Simcikaite, 2012). The results of this study are in alignment with the previous studies since, compared to B1 level learners, $\mathrm{C} 1$ level learners are more proficient in English and more experienced in L2 writing as the native speakers are compared to learners of English.

\section{Ethics Committee Approval}

The author(s) confirm(s) that the study does not need ethics committee approval according to the research integrity rules in their country (Date of Confirmation: March 09, 2020).

\section{References}

Babanoğlu, P. (2014). A Corpus-based Study on the Use of Pragmatic Markers as Speech-like Features in Turkish EFL Learners' Argumentative Essays. Procedia-Social and Behavioral Sciences, 136,186-193.

Cullen, R., \& Kuo, I. (2007). Spoken grammar and ELT course materials: A missing link? TESOL Quarterly, 41 (2): 361-386.

DeVito, J. A. (1965). Comprehension factors in oral and written discourse of skilled communicators. Speech Monographs, 32, 124-128.

Driemann, G. H. J. (1962). Differences between written and spoken language. Acta Psychologica, 20, 36-57.

Gilquin, G.\& Paquot, M. (2007). Spoken Features in Learner Academic Writing: Identification, Explanation and Solution. Proceedings of the 4th Corpus Linguistics Conference, University of Birmingham, 27-30 July 2007.

Hilliard, A. (2014). Spoken Grammar and Its Role in the English Language Classroom. English Teaching Forum, 52 (4), 2-13.

Olson, D.R. (1977b). The language of instruction: The literate bias of schooling. In R. Anderson, R. Spiro \& W. Montague (Eds.), Schooling and the acquisition of knowledge. Hillsdale, NJ: Lawrence Erlbaum Associates.

Park, D. (2007). Identifying \& using formal \& informal vocabulary. IDP Education, the University of Cambridge and the British Council, the Post Publishing Public Co. Ltd.

Schallert, D. L., Kleiman, G. M., \& Rubin, A. D. (1977). Analyses of differences between written and oral language. Center for the Study of Reading, Technical Report No. 29, Urbana: Center for the Study of Reading, University of Illinois. 
Simcikaite, A. (2012). Spoken Discourse Markers in Learner Academic Writing. Studies about Languages, 20, 27- 34.

Stenström, A. (2004). An introduction to spoken inter-action. London: Longman.

Tannen, D. (1984). Coherence in spoken and written discourse. Norwood, NJ: ABLEX Publishing Corporation.

Willis, D. (2003). Rules, patterns and words: Grammar and lexis in English language teaching. Cambridge: Cambridge University Press.

\section{İngilizce'de sözlü dile ait ifadelerin Türk öğrencilerin yazılı çalışmalarında kullanımı}

\section{$\ddot{O} \mathbf{z}$}

$\mathrm{Bu}$ çalışma İngilizce öğrenen Türk öğrencilerin yazılı çalışmalarında sözlü dil ifadelerinin kullanımını araştırmaktadır. Aynı zamanda, bu çalışma kullanılan sözlü dil ifadelerinin sıklığı ve çeşitleri açısından ileri ve orta seviye öğrenciler arasındaki farkları ortaya çıkarmayı amaçlamaktadır. Çalışmanın katılımcıları Türkiye'de bir devlet üniversitesinde öğrenim görmekte olan 21 orta seviyede ve 33 ileri seviyede İngilizce bilen öğrencilerdir. Araştırma için öğrencilerin yazma ödevleri incelenmiştir. Sıklık analizi için kullanılan sözlü dile ait ifadeler sayılmışıır. Sözlü dil ifadelerinin çeşitleri için veri daha önceki çalışmalar temel alınarak farklı gruplara ayrılmıştır. Veri analizi orta seviyede İngilizce bilen öğrencilerin sözlü dil ifadelerini çok daha sık kullandıklarını göstermektedir. Ayrıca, orta ve ileri seviyede İngilizce bilen öğrencilerin kullandıkları sözlü dil ifadelerinin çeşitlerinde de bazı farklılıklar gözlenmiştir.

Anahtar sözcükler: konuşma diline özgü ifadeler; yazılı eser; ileri seviye öğrenciler; orta seviye öğrenciler; İngilizce öğrenen Türk öğrenciler

\section{AUTHOR BIODATA}

Kadriye Aytaç-Demirçivi is working as an instructor in the department of Foreign Languages at Aksaray University. She received her Bachelor's Degree and M.A. Degree in ELT from METU. She is currently a Ph.D. candidate at METU. Her main research interests are corpus linguistics, sociolinguistics, discourse analysis, gender and identity work and conversation analysis. 